Debreceni Jogi Múhely 2015. (XII.) 3-4.

Debreceni Egyetem, Állam- és Jogtudományi Kar, Debrecen

(University of Debrecen, Faculty of Law, Debrecen)

DOI 10.24169/DJM/2015/3-4/8

\author{
Varga Nelli \\ $\mathrm{PhD}$, egyetemi adjunktus \\ Debreceni Egyetem, Állam- és Jogtudományi Kar \\ Polgári Jogi Tanszék
}

\title{
A vétőképtelen személy károkozásáért való felelősség
}

Debreceni Jogi Műhely, 2015. évi (XII. évfolyam) 3-4. szám (2015. december)

DOI $\underline{10.24169 / \mathrm{DJM} / 2015 / 3-4 / 8}$

\section{Bevezető gondolatok}

Bár a kártérítési jog hazai jogirodalma az új Ptk. megalkotása óta elsősorban a kontraktuális kárfelelôsség megváltozott szabályaira, a kontraktuális és deliktuális felelősség eltérő alapokra helyezésére fókuszál, érdemes figyelmet fordítani a deliktuális kárfelelősség speciális alakzatait érintố kisebb-nagyobb újításokra, pontositásokra is. Jelen tanulmány a vétőképtelen személy károkozásáért való felelősség új Ptk.-beli normaszövegét elemzi. Vajon tényleg apróbb módositások történtek ezen speciális kárfelelősségi alakzat esetében, amelyek a már kialakult bírói gyakorlatot nem érintik, avagy a normaszöveg alapvetően nem kardinálisnak tủnő módosításai a bíróságok már kialakult gyakorlatát is befolyásolni fogja? A következőkben szorosan a normaszöveg mentén haladva erre a kérdésre keressük a választ felhasználva a judikatúra régi Ptk. talaján kialakult gyakorlatát és a rendelkezésre álló kommentárirodalmat.

\section{Felelősség vétőképtelen személy által okozott kárért}

Az új Ptk. LXX. fejezete a belátási képességgel korlátozott mértékben rendelkező, vétőképtelen személyek által okozott károk megtérítésének szabályait rendezi. Miközben a fejezet „Felelősség vétóképtelen személy károkozásáért" címet viseli, - a korábbi Ptk.-hoz hasonlóan - tartalmazza a vétőképes kiskorú károkozására vonatkozó rendelkezéseket is.[1]

\subsection{A vétőképtelen személy károkozása}

A Ptk. 6:544. \(1) bekezdése értelmében, akinek belátási képessége oly mértékben korlátozott, hogy a károkozással kapcsolatos magatartása következményeit nem képes felmérni, az általa okozott kárért nem felel. Természetes személyeknél ugyanis a polgári jogi felelősségre vonás alapja, hogy a károkozó vétôképes legyen. A belátási képesség hiánya vagy fogyatékossága, azaz a vétőképtelenség kizárja a károkozó felelősségének megállapítását. Ennek jogalkotói indoka egyrészről az, hogy a kártérítés, mint szankció prevenciós célja, nevelő hatása a vétőképtelen személyeknél nem tudja kifejteni funkcióját, másrészrôl pedig a legtöbb esetben a kártérités reparációs célja sem érhető el, mivel a vétóképtelen személyek általában nem rendelkeznek vagyonnal. A reparációs cél azonban megkívánja azt is, hogy a károsult ilyen esetekben is kártérítéshez jusson. Éppen ezért a vétőképtelen által okozott kárért gondozója tartozik felelősséggel, akinek kötelessége, hogy neveléssel, felügyelettel hatást gyakoroljon a vétôképtelen magatartására.[2] A gondozó felelőssége önálló[3] és nem járulékos, mivel nem más személyért való felelősséget jelent, mint például a munkáltatónak az alkalmazott által okozott kárért való felelôssége. A 
Debreceni Jogi Múhely 2015. (XII.) 3-4.

Debreceni Egyetem, Állam- és Jogtudományi Kar, Debrecen

(University of Debrecen, Faculty of Law, Debrecen)

DOI 10.24169/DJM/2015/3-4/8

gondozó saját felróható magatartásáért, mulasztásáért felel, ami közvetett módon közrehatott a kár bekövetkezésében, illetve amely lehetővé tette a vétőképtelen személy károkozását. A gondozó mentesül a felelősség alól, ha bizonyítja, hogy a nevelés és felügyelet ellátásával kapcsolatban felróhatóság nem terheli. Ez a felelősségi alakzat az általános Ptk. 6:519. \-ában megfogalmazott felelősségi szabályhoz hasonlóan kimentő jellegű, és annak egyik tipizált, de önálló jogalapi hivatkozást lehetővé tevô esete.

\subsection{A vétőképtelenség fogalma}

Az új Ptk. - szemben a korábbi Ptk.-val - a bírói gyakorlaton alapulva meghatározza, hogy kit kell vétőképtelennek tekinteni. E szerint azt a személyt kell vétőképtelennek tekintetni, akinek belátási képessége oly mértékben korlátozott, hogy károkozással kapcsolatos magatartása következményeit nem képes felmérni.[4] A vétôképtelen személy polgári jogi felelőssége nem állapítható meg, kártéritésre pedig nem kötelezhetó.

A vétőképesség azt jelenti, hogy a károkozó a károkozás időpontjában a konkrét károkozó magatartás tekintetében rendelkezik magatartása várható következményeinek felismeréséhez szükséges belátási képességgel, fel tudja-e mérni konkrét magatartásának következményeit.[5] A törvény a vétőképességet korhatárhoz nem köti. Jogvita esetén a bírónak kell a tényállás körültekintô tisztázásával megállapítania, hogy a károkozó a károkozás idején rendelkezett-e belátási képességgel, képes volt-e felfogni magatartásának várható káros következményeit.[6]

Vétőképtelen károkozó magatartásának felróhatósága nem vizsgálható, miután vétőképtelen személy magatartása nem lehet felróható. Esetében a felróható közrehatáson vagy kárenyhítési kötelezettség felróható megszegésén alapuló kármegosztás sem alkalmazható.[7]

A Ptk. nem tesz különbséget a teljes vétőképtelenség és a korlátozott vétőképtelenség között, a belátási képesség teljes hiánya illetve fogyatékossága egyaránt vétőképtelenséget eredményez.

Hangsúlyozandó, hogy a vétóképtelenség és a cselekvőképtelenség kategóriája nem azonos fogalmak, ami egyben azt is jelenti, hogy nem minden cselekvôképtelen vagy korlátozottan cselekvőképes személy egyben vétőképtelen is. A cselekvőképesség azt jelenti, hogy valaki saját akarat-elhatározásából, saját nevében jogokat szerezhet, kötelezettségeket vállalhat, azaz jogügylet alanya lehet. Ezzel szemben a vétőképesség a polgári jogi felelősségre vonás feltétele, aminek - szemben a cselekvőképességgel - fokozatai sincsenek, és jogszabályban rögzített életkorhoz sem köthető. A teljesen cselekvőképtelen tizennégy éven aluli kiskorú vagy gondnokság hatálya alatt álló nagykorú is lehet vétôképes, vagy a gondnokság alá nem helyezett nagykorú is lehet vétőképtelen. A bírósági gyakorlat az életkorának megfelelően fejlett tizenkét éves kiskorút általában már vétőképesnek tekinti, de adott esetben e korhatár alatt is megállapítja a vétőképességet és e felett is a vétőképtelenséget.

A vétőképességet nem lehet a büntetőjogi felelősségre vonáshoz szükséges korhatárhoz sem kötni. Az a gyermek, aki életkora miatt büntetőjogi felelősségre nem vonható, adott esetben polgári jogilag mégis vétőképes lehet. Általánosságban azonban megállapítható, hogy aki büntetőjogilag felelős és felelősségre vonható, az általában polgári jogi szempontból is vétôképes.

A bíróságoknak minden egyes ügyben külön-külön kell dönteniük arról, hogy a károkozó vétőképtelennek minősül-e. Ennek keretében vizsgálniuk kell a károkozó életkorát, szellemi állapotát, értelmi képességei, tulajdonságait, valamint a konkrét károkozási helyzetet, a jogellenes magatartást és a károkozás egyéb 
Debreceni Jogi Múhely 2015. (XII.) 3-4.

Debreceni Egyetem, Állam- és Jogtudományi Kar, Debrecen

(University of Debrecen, Faculty of Law, Debrecen)

DOI 10.24169/DJM/2015/3-4/8

körülményeit.[8] Előfordulhat, hogy a károkozó vétőképességét bizonyos károkozás tekintetében meg lehet állapítani, más esetben viszont nem. A kilencéves általános iskolai tanuló vétőképessége és felelôssége megállapítható abban az esetben, ha bosszúból szándékosan betöri a szomszéd ablakát, ellenben nem állapítható meg, ha labdázás közben gondatlanul teszi ugyanezt. Egy tizenkét éves kiskorú vétőképes a bicskázással okozott kár tekintetében, míg vétôképtelen a vasúti váltóval való játszadozás során okozott kár körében. Vétőképes a szünetben figyelmeztetés ellenére kővel dobálózó 14 éves kiskorú, aki eltalálja társa szemét.

Nem állapította meg a bíróság annak a 10 és féléves kiskorúnak a vétőképességét, aki egy be nem kerített ingatlanra a barátjával bejutva a kerti szalonnasütőben tűzet rakott, majd egy füstölgó bottal masírozva katonásdit játszott, miközben a botról lehulló parázsdarab meggyújtotta a nádtetôt és a házban tűz ütött ki.[9] Ellenben vétóképesnek tekintette a bíróság azt a tízéves iskolába egyedül közlekedő kiskorút, aki jó tanuló volt, a balesetet megelőző években már egyedül közlekedett, jól ismerte az utat, ahol a baleset bekövetkezett, és szülei úgy ítéleték meg, hogy biztonságosan közlekedik, alkalmas a felügyelet nélküli balesetmentes közlekedésre. Az eljáró bíróság rögzítette, hogy vétőképtelenség nincs konkrét életkorhoz kötve, a törvény annak ismérveit sem határozza meg. A közlekedési baleset alapján kártérités iránt indult perben ezért a bíróságnak a károsult vétőképességének megitélése érdekében vizsgálnia kell, hogy a károsult a baleset bekövetkezésekor ismerte-e a közlekedési szabályokat, képes volt-e azok megértésére, illetve képes volt-e felismerni a közlekedési szabályok megszegésének veszélyeit, annak lehetséges következményeit, így elvárható volt-e tőle a szabályok betartása. Ha a kiskorú károsult vétőképes volt, felróható közrehatása lehetőséget ad a kármegosztásra.[10] [11]

\subsection{A gondozó fogalma}

Az új Ptk. - szemben a korábbi Ptk.-val - meghatározza a vétőképtelenség mellett a gondozó fogalmát is. A korábbi bírói gyakorlathoz hasonlóan a jogalkotó két személyi kört nevesít a vétóképtelen személyek gondozójaként: a.) jogszabály alapján a vétőképtelen személy gondozójának minősülő személy (állandó gondozó), b) a vétôképtelen személy felügyeletét a károkozáskor ténylegesen ellátó személyt.

Ha a kár bekövetkezésében mind a vétőképtelen személy felügyeletét a károkozás időpontjában ténylegesen ellátó személy, mind pedig a jogszabály alapján gondozónak minősülő személy által elkövetett súlyos nevelési hiba közrehatott, akkor felelősségük, mint közös károkozóké a Ptk. 6:524. \-a alapján egyetemleges.[12]

A vétőképtelen személyeknek egyidejúleg több gondozója is lehet. Ha gondozók a felelősség alól kimenteni nem tudják magukat, felelősségük, mint közös károkozóké egyetemleges.

\section{a) A jogszabály alapján a vétőképtelen személy gondozójának minősülő személy (állandó gondozó)}

Az új Ptk. normaszövege alapján azt kell gondozónak tekinteni, aki jogszabály alapján a vétóképtelen személy gondozójának minősül. A kiskorú vétőképtelen károkozó gondozója elsősorban a szülői felügyeletet gyakorló szülő, mégpedig mindkét szüllö (örökbefogadó, nevelőszülő is), még akkor is, ha az egyik tartósan külföldön tartózkodik. A szülők a Ptk. 4:164. \(1) bekezdése alapján a szülői felügyeletet megállapodásuk, vagy a gyámhatóság, vagy a bíróság eltérő rendelkezése hiányában - közösen gyakorolják akkor is, ha már nem élnek együtt. Ha a szülóknek csak az egyike jogosult a szülői felügyeleti jog gyakorlására, akkor értelemszerűen a másik szülőt főszabályként nem kell gondozónak tekinteni. Szülői felügyelet hiányában gondozó a gyámhatóság által kirendelt gyám, gyermekotthon, nevelös zülló. (Mivel a 
Debreceni Jogi Múhely 2015. (XII.) 3-4.

Debreceni Egyetem, Állam- és Jogtudományi Kar, Debrecen

(University of Debrecen, Faculty of Law, Debrecen)

DOI 10.24169/DJM/2015/3-4/8

nevelőszülő foglalkoztatási jogviszonyban áll, így károkozás esetén az alkalmazott károkozásáért való felelősség (Ptk. 6:540. §) szabályait kell alkalmazni.) Nagykorú vétőképtelen személy esetén nem tekinthető gondozónak a gyámhatóság által kirendelt gondnok, miután a gondnokot gondozási kötelezettség jogszabály alapján nem terheli. Gondozó lehet többek között az idösek otthona, a pszichiátriai betegek otthona, a szenvedélybetegek otthona, stb.[13]

\section{b) A vétőképtelen személy felügyeletét a károkozáskor ténylegesen ellátó személy}

Gondozónak kell tekinteni azokat a személyeket is, akik a vétóképtelen felügyeletét a károkozáskor ténylegesen ellátják. Így gondozó lehet a szülői felügyeleti jogot nem gyakorló szülő, ha a károkozás idôpontjában kapcsolattartási jogával él. Gondozónak minősül a nagyszülő vagy más rokon, akinél a gyermek tartózkodik, vagy bárki más, akire a szülő gyermeke felügyeletét akárcsak néhány órára rábízza. Gondozók lehetnek azok, akik akár ingyenesen, akár ellenérték fejében vigyáznak a vétóképtelen személyre, így babysitter, családi napközi, táboroztató cég, vagy szervezet. Vétőképtelen személy gondozója az óvoda, az iskola, a napközi otthon, a kollégium, a kórház vagy más intézet az alatt az idő alatt, amíg a vétőképtelen személy ott tartózkodik.

Nem gondozója a vétőképtelen személynek az, aki a felügyeletet munkaviszony alapján látja el, pl. a tanár, óvónő, nevelő, a kórházi orvos. A gondozó ilyen esetben az, aki az adott munkavállalót alkalmazza.

Az iskola, óvoda nem feltétlenül a Ptk. 6:544. \-a alapján felel az egyik gyermek által a másik gyermeknek okozott kárért, hanem amennyiben a kár tanulói jogviszonnyal, óvodai elhelyezéssel okozati összefüggésben következik be, úgy az intézmény objektív felelőssége állapítható meg a nemzeti köznevelésrôl szóló 2011. évi CXC. tv. 59. \(3) bekezdése alapján, kivéve ha az intézmény bizonyítja, hogy a kárt múködési körén kívül eső elháríthatatlan ok, így többek között a károsult elháríthatatlan magatartása idézte elő. A kimentés körében nem minősül múködési körön kívül eső, elháríthatatlan oknak a tanulók tanulási képességbeli hiányossága.[14] Ugyanakkor az állandó felügyeletre szoruló autista fogyatékos kiskorú gyermeknek a felügyeletet ellátó oktatási intézményből engedély nélküli eltávozása folytán bekövetkezett közúti balesete akkor is a felügyelet elmulasztására vezethetô vissza, ha magát a balesetet a kiskorú elháríthatatlan magatartása okozta.[15]

Az iskola felelőssége a tanulói jogviszonnyal összefüggésben okozott kárért objektív. A felelősség alól csak akkor mentesülhet, ha bizonyítja, hogy a kárt múködési körén kívül eső elháríthatatlan ok idézte elő. Nem kell megtéríteni a kárt akkor sem, ha azt a károsult elháríthatatlan magatartása okozta. Az iskola felelőssége tehát nem felróható magatartásától függő, hanem objektív alapú: azt a tanulói jogviszony és a kár közötti okozati összefüggés alapozza meg.[16] Az iskola objektív felelőssége a gyermek iskolába érkezésétől a távozásáig fennáll, és nem korlátozódik csupán a tanítási órákra. Az oktatási intézmény helytállni tartozik az óraközi szünetekben bekövetkezett balesetért is, mert a gyermek akkor is tanulói jogviszonya alapján tartózkodik az iskolában. A bíróság egy jogeset kapcsán rögzítette,[17] hogy általános jogelv, hogy a speciális szabály megelőzi az általánost, ezért ha az iskola kártérítési felelőssége a speciális - objektív felelősség szabályai alapján megállapítható, úgy mellőzni kell az általános, gondozói felelősség feltételei fennállásának vizsgálatát.[18]

A gondozói kör fogalmi definiálásával a jogalkotó a korábbi Ptk. talaján kialakult bírói gyakorlatot kívánta a kódexbe emelni. A bírói gyakorlat szerint gondozó egyrészt a vétőképtelen nevelését végzô személy, másrészt a tényleges felügyeletét ellátó személy. Az új Ptk. látszólag hasonló megoldást követ, amikor gondozóként definiálja egyrészrôl a „a jogszabály alapján a vétőképtelen gondozójának minősülő személyt" (állandó gondozó) és a vétôképtelen felügyeletét a károkozáskor ténylegesen ellátó személyeket. 
Debreceni Jogi Múhely 2015. (XII.) 3-4.

Debreceni Egyetem, Állam- és Jogtudományi Kar, Debrecen

(University of Debrecen, Faculty of Law, Debrecen)

DOI 10.24169/DJM/2015/3-4/8

A felügyeletet a károkozás időpontjában ténylegesen ellátó személyt illetően a gondozói kör valóban azonos, ugyanakkor a nevelést ténylegesen végző személy esetén a bírói gyakorlat a régi Ptk. alapján a tényhelyzetet vizsgálja, azaz azt, hogy ki látja el ténylegesen a vétőképtelen kiskorú nevelését. Ezzel ellentétben az új Ptk. a jogkérdésre helyezi a hangsúlyt, azaz ki az, akit a jogszabály alapján a vétőképtelen gondozójának kell tekinteni.[19] Álláspontom szerint ez a bírói gyakorlatban is némi módosulást fog eredményezni a jövőben, hiszen a bíróságoknak azt kell vizsgálniuk, hogy ki tekinthető a jogszabály alapján a vétôképtelen személy gondozójának, és ha olyan személy látja el a vétőképtelen nevelését, gondozását, aki erre jogszabály alapján nem lenne köteles, felelősségre nem vonható, kivéve, ha a károkozás időpontjában a vétőképtelen tényleges felügyeletét ellátta. Ez a normabeli megfogalmazás akkor adhat aggályra okot, ha a gyerekvédelmi intézményrendszer kiterjedt eszköztára ellenére egy gyermeket nem azon személy nevel, aki a jogszabály alapján a vétőképtelen gondozójának minősül.

\subsection{A vétőképtelen személy gondozójának kimentési lehetősége}

A vétőképtelen személy gondozójának felróhatóságát a törvény vélelmezi, de a vélelem megdönthető, és a gondozó bizonyíthatja, hogy a nevelés és a felügyelet ellátásával kapcsolatban felróhatóság nem terheli, vagyis úgy járt el, ahogy az az adott helyzetben általában elvárható. Ha a felügyeletet a károkozás időpontjában nem az állandó gondozó látta el, hanem valaki más, akkor a felügyelet kapcsán az ő magatartását kell vizsgálni. E körben vizsgálni kell, hogy a felügyelet ellátása a vétóképtelen életkorára, tulajdonságaira, személyiségére tekintettel megfelelő volt-e, ha pedig felügyelet nélkül hagyta a vétôképtelent, akkor szükség lett volna-e felügyeletre. Fennáll a gondozó felelőssége, ha a szülők mialatt a parkolóban beszélgetnek a vétőképtelen gyermekek kővel megkarcolják a parkoló gépkocsik ajtaját.

Ha a károkozás visszavezethető súlyos nevelési hibára, akkor az állandó gondozó felelőssége is megállapítható annak ellenére, hogy a károkozás időpontjában a vétőképtelen tényleges felügyeletét nem ő látta el. A gondozónak ugyanis kötelezettsége, hogy a kiskorú vétőképtelen egyéniségét formálja, alakítsa, vagyis nevelje a gondozottat. Ez alapján a gondozó akkor mentesülhet a felelősség alól, ha bizonyítja, hogy súlyos nevelési hibát nem vétett. A károkozó hiányos vagy fogyatékos belátási képessége miatti gondozói felelősség körében a gondozói kötelesség vizsgálatánál nemcsak azt a kérdést kell tisztázni, hogy a gondozó a károkozást megakadályozhatta volna, hanem azt is mérlegelni kell, hogy a szülők a gyermek nevelése, jellemének, szokásainak kialakulása körül úgy jártak-e el, ahogy ez az adott helyzetben általában elvárható.[20]

\section{Kártérítés méltányosság alapján}

Ha a károkozónak nincs gondozója, vagy a gondozó felelősségét nem lehet megállapítani, kivételesen a vétőképtelen károkozót is kötelezni lehet a kár részben vagy egészben való megtérítésére, feltéve, hogy az eset körülményei és a felek vagyoni viszonyai ezt nyilvánvalóan indokolttá teszik.[21]

Az új Ptk. a korábbi Ptk.-val egyező módon változatlanul fenntartja a méltányosságon alapuló kártelepítési szabály arra az esetre, amikor a károkozónak nincsen gondozója, vagy a gondozó a felelósségét kimenti. A méltányosság alkalmazásának kettős feltétele van: a) vétőképtelennek egyáltalán nincs gondozója, vagy van ugyan, felelőssége azonban nem állapítható meg, b) a felek anyagi helyzete és az eset körülményei a méltányosság gyakorlását indokolttá teszik.

Ezekben az esetekben fó szabály szerint a károsultnak kellene viselnie a vétőképtelen személy által okozott kárt. Kivételesen azonban lehetőség van arra, hogy a bíróság méltányossági alapon a károkozót kötelezze 
Debreceni Jogi Múhely 2015. (XII.) 3-4.

Debreceni Egyetem, Állam- és Jogtudományi Kar, Debrecen

(University of Debrecen, Faculty of Law, Debrecen)

DOI 10.24169/DJM/2015/3-4/8

kártérítés megfizetésére. Ilyekor a kártérítés méltányosságon alapul. Azt, hogy méltányosság alapján helye lehet-e kártérítésnek, a bíróságnak a felek anyagi helyzetét, illetve az eset körülményeit mérlegelve kell eldöntenie. A méltányosságon alapuló felelósségi szabálynak ugyanis a célja, hogy a károsult - anyagi viszonyaira tekintettel - ne legyen kénytelen jelentős mértékű kár viselésére olyan esetben, amikor a vétőképtelen károkozó anyagi viszonyai és az eset összes körülményei egyébként a kártérítést lehetővé tennék. Ez alapján a méltányossági kártérítés alkalmazható, ha a vétőképtelen károkozónak jelentős ingó, ingatlan vagyona, vagy rendszeres jövedelme van, míg a károsult vagyontalan, nehéz anyagi körülmények között élő személy. Az anyagi helyzeten túlmenően azonban vizsgálni kell az eset egyéb körülményeit is, így a károsult kárenyhítés, kármegelőzés érdekében kifejtett tevékenységét, esetleges közrehatását. A bírói gyakorlat szerint a méltányossági kártérítés feltételei fennállnak, ha a vétőképtelen károkozó ingatlan vagyonnal rendelkezik és a kártérítés kisebb összegű.[22]

Annak ellenére, hogy a bírói gyakorlat meglehetősen ritkán alkalmazza a méltányosságon alapuló kártérítés lehetőségét, és hangsúlyozza a méltányossági kártérítés alkalmazásának kivételes lehetőségét,[23] a jogalkotó az új Ptk.-ban továbbra is fenntartotta a méltányosságon alapuló kártérítés jogintézményét. Ennek oka a Ptk. indokolása szerint az, hogy a jogalkalmazás során előfordulhat olyan tényállás, amikor indokolt a felelősségre nem vonható vétóképtelen károkozó marasztalása. [24]

\section{A károkozó önhibája}

Nem hivatkozhat a belátási képességének hiányára vagy fogyatékosságára az a személy, aki ezt az állapotát felróhatóan maga idézte elő (actio libera in causa). [25] Az új Ptk. ezen szakasz a korábbi Ptk.-hoz hasonlóan sajátos szabályt fogalmaz azokra nézve, aki vétőképtelenségüket maguk idézték elő. A jogi norma összhangban van a polgári jog azon általános alapelvével, mely szerint a polgári jogi viszonyokban úgy kell eljárni, ahogy az adott helyzetben elvárható, felróható magatartására előnyök szerzése végett senki sem hivatkozhat. (Ptk. 1:4. \(1)-(2) bekezdés). Ezekben az esetekben tehát a kár releváns oka az egyébként vétőképes személynek az a magatartása, amellyel magát vétőképtelen állapotba hozza, vagyis a belátási képesség csökkenését illetve hiányát felróhatóan maga idézi elő.

Tipikusan ide tartoznak azok az esetek, amikor a károkozó italozás, vagy kábítószer hatására veszti el belátási képességét, és ebben az öntudatlan állapotban okoz kárt. Nyilvánvalóan azonban nem alkalmazható a szabály, ha valaki például súlyos közlekedési balesetet okozva vagy vétóképtelenséget előidéző anyag fogyasztására kényszerítés révén kerül vétőképtelen állapotba, tehát magatartása nem felróható. A felelősség szempontjából közömbös, hogy a károkozó a felelősség alóli mentesülés érdekében vagy más okból hozta-e magát ilyen állapotba. (Például aki ittas állapotban verekedik, és ennek során kárt okoz, nem hivatkozhat vétóképességének hiányára akkor sem, ha nem azért ivott, hogy a testi bántalmazást ittas állapotban kövesse el). A lényeg, hogy a károkozó abban a folyamatban, amely a belátási képesség hiányát vagy fogyatékosságát előidézte, nem úgy járt el, ahogy az adott helyzetben elvárható, azaz magatartása felróható. Ha a vétőképtelen állapot előidézése a károkozónak nem felróható, akkor felelőssége - vétőképesség hiányában - nem megállapítható. Ha az érintett személy nem tudott és nem is kellett tudnia arról, hogy magatartása a belátási képességének hiányát, vagy fogyatékosságát fogja előidézni, felelősségre vétôképtelensége miatt nem vonható (pl.: károkozó italába, ételébe gyanút nem keltő módon tudatmódosító szert tesznek).

A Ptk. 6:546. \-ára akkor lehet hivatkozni, ha a károkozó egyébként rendelkezik vétôképességgel (nem tartozik ide egy vétôképtelen 7 éves kiskorú, vagy akit idült alkoholizmus miatt gondnokság alá helyeztek) és belátási képessége kiterjed arra, hogy magatartása belátási képességének hiányát, fogyatékosságát fogja eredményezni (pl.: a túlzott alkoholfogyasztás miatt olyan öntudatlan állapotba kerül, ami miatt nem tudja cselekményeit kontrollálni). Tehát a belátási képességnek nem a károkozás közvetlen okát, azaz a károkozó 
Debreceni Jogi Múhely 2015. (XII.) 3-4.

Debreceni Egyetem, Állam- és Jogtudományi Kar, Debrecen

(University of Debrecen, Faculty of Law, Debrecen)

DOI 10.24169/DJM/2015/3-4/8

magatartást és annak lehetséges következményeit kell átfognia, hanem azt a folyamatot, amely a károkozó vétőképtelenséget előidézi.

Annak ellenére, hogy a jogirodalomban többen is foglalkoztak az actio libera in causa problematikájával bírói jogalkalmazására ritkán kerül sor.

\section{Felelősség vétőképes kiskorú károkozásáért}

Ha a kárt olyan vétőképes kiskorú okozta, akinek van felügyeletre köteles gondozója, és a károsult bizonyítja, hogy a gondozó kötelességét felróhatóan megszegte, a gondozó az okozott kárért a károkozóval egyetemlegesen felelős.[26] A vétőképtelen személy által okozott károkét csak a gondozó felel, felelőssége kimentési jellegû, vagyis a gondozó felróhatósága vélelmezett, a kimentés érdekében neki kell bizonyítani, hogy úgy járt el, ahogy az az adott helyzetben általában elvárható. Ezzel szemben vétőképes kiskorú károkozása esetén a gondozó a károkozóval egyetemlegesen felel, és a felróhatóságot is a károsultnak kell bizonyítania (direkt bizonyítás). A vétőképes kiskorú károkozó és gondozó egyetemleges felelősségét megalapozó szabály megalkotásakor a jogalkotó figyelemmel volt egyrészről arra a körülményre, hogy a kiskorú károkozó általában még nem rendelkezik olyan egzisztenciával, ami alapot adna az okozott kár megtérítésére. Másrészrôl pedig a gondozó felelősségének fenntartását indokolja az is, hogy a kiskorú magatartására - vétőképessége ellenére - a gondozó még jelentős befolyást gyakorol, így mulasztásának szerepe lehet a vétőképes kiskorú károkozásában. Éppen ezért, amennyiben a kárt okozó vétőképes kiskorúnak felügyeletre köteles gondozója van, aki kötelességét felróhatóan megszegte, úgy felelősségük a károsult irányban egyetemleges. A vétőképes kiskorú és a gondozó belső jogviszonyában a felelősség az általános szabályok szerint alakul.

A kiskorú károkozó és a felügyeletre köteles gondozó egyetemleges felelősségét megállapító szabály több szempontból is eltérést mutat a vétőképtelen kiskorú gondozójának felelősségétől. A különbségek az alábbiakban állnak: a) a kárt vétőképes kiskorú okozza, akinek felelőssége megállapítható, b) a kárért csak a felügyeletre köteles gondozó felel, c) a gondozó mulasztásának felróhatóságát a károsultnak kell bizonyítania, tehát a felelősség nem kimentési jellegú, hanem direkt, a felróhatóság vélelme nem áll fenn, d) a kiskorú és gondozójának a felelőssége egyetemleges.

\section{a) Vétőképes kiskorú}

A károkozó vétőképességét a bíróságok minden egyes ügyben esetenként vizsgálják a 6:544. \-ánál leírtak alapján. A Ptk. 2:10. \-a alapján kiskorú az, aki a tizennyolcadik életévét nem töltötte be. A kiskorú a házasságkötéssel nagykorúvá válik. Ha a házasságot a bíróság a cselekvőképesség hiánya vagy a kiskorúság miatt szükséges gyámhatósági engedély hiánya miatt érvénytelennek nyilvánítja, a házasságkötéssel szerzett nagykorúság megszűnik. A házasságkötéssel megszerzett nagykorúságot a házasság megszűnése nem érinti.

\section{b) Felügyeletre köteles gondozó}

Ha a kárt okozó vétőképes kiskorú, akkor az egyetemleges felelősség megállapításához szükséges, hogy a kiskorúnak felügyeletre köteles gondozója legyen. A gondozó felügyeleti kötelezettsége alapulhat jogszabályon (pl.: a szülő szülői felügyeleti joga), hatósági, bírósági határozaton (pl.: gyámhatósági gyámrendelést tartalmazó határozat, szülői felügyeleti jog gyakorlásáról rendelkező bírósági ítéleten stb.) és szerződésen. Szerződésen a felügyeleti kötelezettség, ha a szülő táborba küldi vétôképes, de még kiskorú gyermekét, vagy babysiter-re, rokonra, családi barátra bízza távolléte idejére gyermekét. Ez a személy alkalmi jelleggel vigyáz a vétőképes kiskorúra.[27] 
Debreceni Jogi Múhely 2015. (XII.) 3-4.

Debreceni Egyetem, Állam- és Jogtudományi Kar, Debrecen

(University of Debrecen, Faculty of Law, Debrecen)

DOI 10.24169/DJM/2015/3-4/8

\section{c) Direkt bizonyítás - károsult bizonyít}

Míg a vétőképtelen károkozása esetén a Ptk. 6:544. \(3) bekezdése lehetőséget ad a gondozó számára arra, hogy kimentse magát a felelősség alól, addig vétőképes kiskorú károkozása esetén a bizonyítási teher megfordul, és a károsultnak kell bizonyítania, hogy a gondozó kötelezettségét felróhatóan megszegte. Jelen esetben tehát nem érvényesül a felróhatóság vélelme, a gondozót nem terheli bizonyítási teher a felelősség alóli kimentést illetôen. Vétőképes kiskorú károkozása esetén ugyanis direkt bizonyítás elve érvényesül, a bizonyítás sikertelenségét a károsult viseli.[28]

A felügyeleti kötelezettség tartalma ebben az esetben is azonos a vétőképtelen kiskorú gondozójának kötelezettségével. Ezeknél a károkozásoknál is azt kell vizsgálni, hogy a gondozó a felügyelet, nevelés, ellenőrzés terén felróható módon megszegte-e kötelezettségét, azaz mulasztás terheli-e körben. Önmagában az a tény, hogy a vétóképes kiskorú már munkát vállalt, nem jelenti egyben azt is, hogy kikerült a gondozói felügyelet alól. Ha a károkozás a gondozó súlyos nevelési hibájára vezethető vissza a károkozóval egyetemlegesen felel a felügyeletre köteles gondozó is.

\section{d) Egyetemleges felelősség}

A kiskorú és felügyeletre köteles gondozója a vétőképes kiskorú által okozott kárért a károsulttal szemben egyetemlegesen felel. A kiskorú azonban kimentheti magát a felelősségé alól annak bizonyításával, hogy úgy járt el, ahogy az az adott helyzetben általában elvárható, illetve hivatkozhat a károsult felróható közrehatására is.

Annak ellenére, hogy vétőképes kiskorú esetén a felügyelet kevésbé szoros és a gondozó felróhatóságát a károsultnak kell bizonyítania, a bírói gyakorlatban a felügyeletre köteles gondozó elvárhatósági mércéjének szigorodása figyelhető meg az utóbbi időben, és önmagában az erkölcsi nevelés elmulasztása megalapozza a gondozó vétőképes kiskorúval való egyetemleges felelósségét a károsult irányába.[29] Egy jogeset kapcsán a bíróság megállapította, hogy a vétőképes kiskorú által légpuskával okozott kárért a szülők a károkozóval egyetemlegesen felelnek, mivel a szülők több alkalommal eltűrték, hogy gyermekük légpuskával lövöldözzön.[30] Egy másik esetben a vétőképes kiskorú hajtotta a lovaskocsit a múúton, amikor balesetet okozott. A bíróság szerint a vidéki környezetben élő vétőképes kiskorú bár képes a lovaskocsit hajtani, de a forgalmas múútra nem lett volna szabad kiengedni, mert nem rendelkezett még a váratlan helyzetek kivédéséhez szükséges lélekjelenléttel, ezért a károkozó vétőképes kiskorú gondozójával egyetemlegesen feleltek.[31] Az a körülmény, hogy a 14 éves kiskorú gyermek gázpisztollyal rendelkezik és annak használata során kárt okoz, szintén a gondozó felróható kötelességszegésének minősül, és megalapozza a gondozó és a károkozó egyetemleges felelősségét.[32]

Az utóbbi évtizedben a judikatúra hangsúlyozza, hogy a szülő kötelessége többek között, hogy kiskorú gyermeke magatartását, életvitelét ellenórizze, irányítsa és tegyen meg mindent gyermeke jellemének, szellemi képességének és tulajdonságainak alakítása érdekében. Ennek elmulasztása megalapozza a gondozó és a vétőképes kiskorú egyetemleges felelősségét a károkozásáért.[33] A belátási képességgel rendelkező kiskorú felügyeletre köteles gondozója nevelési, felügyeleti kötelezettségét felróhatóan megszegi, ha a kiskorú helyes irányú erkölcsi fejlődéséről nem gondoskodik. A szülőnek nevelési kötelezettsége körében a kiskorú gyermeknek át kell adnia az általános erkölcsi normákat, a kiskorú jellemét, értékrendjét és szokásait a társadalom által elfogadott erkölcsi kívánalmakkal összhangban kell alakítania. Az élet és az emberi méltóság feltétlen tisztelete az erkölcsi nevelés centrális eleme, a kiskorú gyermek szocializálásának, érzelmi intelligenciája kialakulásának központi magja. A helyes erkölcsi és családi nevelés e legfontosabb szempontjai sérülnek akkor, ha a kiskorú gondviselője nem tesz meg mindent azért, hogy ezeket az értékeket a kiskorúnak átadja, és ezáltal elmulasztja a kiskorú gyermek 
Debreceni Jogi Mühely 2015. (XII.) 3-4.

Debreceni Egyetem, Állam- és Jogtudományi Kar, Debrecen

(University of Debrecen, Faculty of Law, Debrecen)

DOI 10.24169/DJM/2015/3-4/8

érzelmi stabilitásának, lelki kiegyensúlyozottságának és mentális egészségének a legmegfelelőbb alakítását. Ezeknek a kötelezettségeknek a felróható elmulasztásáért a gondozó felelős. Ezért megállapította a bíróság azoknak a szülőknek a vétőképes kiskorú károkozókkal való egyetemleges felelősségét a károsult irányába, akiknek gyermekei egy erdős területen lévő tó partjára csalták barátjukat, aki hosszas bántalmazás és fojtogatás eredményeként eszméletét vesztette. A vétőképes kiskorúak a még életjeleket mutató áldozatukat a derítótóba dobták, és mivel a test nem süllyedt el, ezért nehéz köveket dobáltak rá, melynek következtében az áldozat vízbefulladás miatt életét vesztette.[34] Az utóbbi években minősítette a bíróság súlyos nevelési hibának, amiért a szülő a vétőképes kiskorú gyermekével egyetemleges felelősséggel tartozik, ha a szülő a gyermekét ért iskolai sérelem elhárítása érdekében a gyermeke által számítógépen terjesztett meztelen női alakot ábrázoló képet az országos média részére hozzáférhetővé teszi, azt állítva, hogy a képen a gyermek iskolai tanárnője látható. 35]

\section{Záró gondolatok}

A vétőképtelen személy károkozásáért való felelősség szabályai alapvetően nem változtak az új Ptk. hatályba lépésével. A vétőképtelenség és gondozó fogalmának meghatározása ugyanakkor álláspontunk szerint a bírói gyakorlatban némi változást fog a jövőben eredményezni. A károkozó vétőképtelenségét a judikatúrának a tényállás alapos feltárását követően a károkozóra és a konkrét káreseményre fókuszálva kell elbírálnia, melynek során az életkornak legfeljebb konkrét tényállások esetén lehet szerepe. A gondozó kódex szintű fogalmi definiálása a korábbitól eltérő megközelítést igényel a jogalkalmazóktól, hiszen nem a nevelést ténylegesen ellátó gondozói kört, hanem a jogszabályok alapján gondozónak minősülő személyeket kell meghatározniuk. Helyesen rögzítette a kódex, hogy a vétóképtelen károkozónak egyszerre több gondozója is lehet, akik egyetemlegesen felelnek. Megfontolandó lett volna ugyanakkor a gyakorlatban nem élő, és kivételesen alkalmazott méltányosságon alapuló kártérítés mellózése az új kódexből.

\section{Summary - Liability for dameges caused by a person of lack of discretionary power}

The new Hungarian Civil Code also modernizes the non-contractual liability law in several aspects. Even if the so-called general clause of non-contractual liability reamains unchanged, its contstitutive elements are regulated in detail in the new Civil Code. The new Code also introduces some new provisions with regard to liability for dameges caused by a person of lack of discretionary power. The objektive of this survey is to present these changes and to examine its possible impacts on judicial practice.

[1]Fuglinszky Ádám: Kártérítési jog, HVG-ORAC Lap- és Könyvkiadó Kft., Budapest, 2015., 467. o.

[2] Fuglinszky Ádám In: Osztovits András (szerk.): A Polgári Törvénykönyvről szóló 2013. évi V. törvény és a kapcsolódó jogszabályok nagykommentárja IV. kötet, Opten Informatikai Kft., Budapest, 2014., 184. o.

[3] Lábady Tamás In: Vékás Lajos - Gárdos Péter (szerk.): Kommentár a Polgári Törvénykönyvhöz, Walter Kluwer, Bp., 2014., 2289.

[4] Ptk. 6:544. \ (1) bekezdés

[5] Lábady Tamás In: Vékás Lajos (szerk.): A Polgári Törvénykönyv magyarázatokkal, Complex Kiadó, Bp., 2013., 478.

[6] BDT 2003. 834.

[7] BDT 2007.1513. 
Debreceni Jogi Múhely 2015. (XII.) 3-4.

Debreceni Egyetem, Állam- és Jogtudományi Kar, Debrecen

(University of Debrecen, Faculty of Law, Debrecen)

DOI 10.24169/DJM/2015/3-4/8

[8] Havasi Péter In: Petrik Ferenc (szerk.): Kommentár a gyakorlat számára, Negyedik kiadás, HVGORAC Lap- és Könyvkiadó Kft., Budapest, 2014., 478. o.

[9] Győri Ítélőtábla Pf.20453/2009/5.

[10] BDT 2013. 2972.

[11] További esetek leírását lásd bővebben: Varga Nelli: A vétóképtelen személy károkozásáért való felelősség In: Fézer Tamás (szerk.): A kártérítési jog magyarázata, Complex Kiadó, Bp. 2010., 229-230. o., Fuglinszky: Ádám: i.m., 472.

[12] Ptk. 6:544. \(4) bekezdés

[13] A gondozói kör részletesebb kifejtését lásd Fuglinszky Ádám: i.m., 475-479.

[14] BDT 2005. 1155.

[15] BDT 2011. 2393.

[16] BDT 2003. 855.

[17] Egyet lehet érteni Fuglinszky Ádám azon álláspontjával, hogy attól, hogy ezen felelősségi alakzat ágazati jogszabályban került megfogalmazásra még nem teszi a normát lex specialis-sá a Ptk.-val szemben. Lásd Fuglinszky Ádám: i.m., 488.

[18] BDT 2002. 677.

[19]Bővebben lásd: Fuglinszky Ádám: i.m., 473.

[20] BH 1980.129.

[21] Ptk. 6:545. \$

[22] BDT 2006. 1341.

[23] BH 1988.402.

[24] 2013. évi V. tv. (új Ptk.) indokolása

[25] Ptk. 6:546. \

[26] Ptk. 6:547. \$

[27] Fuglinszky Ádám: i.m., 489. o., Nochta Tibor, In: Csehi Zoltán (szerk.): Az új Polgári Törénykönyv magyarázata, Kommentár a 2013. évi V. törvényhez, Menedzserpraxis, 2014., 519.

[28] BH 1995. 214.

[29] Lábady Tamás: A deliktuális felelősség fontosabb változásai, In: Vékás Lajos-Vörös Imre (szerk.): Tanulmányok az új Polgári Trövénykönyvhöz, Complex Kiadó, Bp., 2014., 287.

[30] BH 1975. 69.

[31] PJD I. 156.

[32] FPK 1996/43.

[33] BDT 2006. 1341.

[34] BDT 2010. 2364.

[35] BDT 2011. 2549. 